\title{
GEOLOGIC MAP OF THE BAYHORSE AREA, CENTRAL CUSTER COUNTY, IDAHO
}

\author{
By
}

\author{
S.W. Hobbs, W.H. Hays, and D.H. McIntyre
}

\section{INTRODUCTION}

The Bayhorse area of this report includes the Clayton and Lone Pine Peak 15-minute quadrangles, the Potaman Peak and Ziegler Basin 7 1/2-minute quadrangles, and small parts of several other adjoining quadrangles, all of which are in central Custer County, Idaho. Its name derives from the old mining town of Bayhorse and the surrounding Bayhorse mining district. The valley of the Salmon River, which trends easterly and northeasterly across the central part of the area, provides access by major highway, and the town of Challis, which is barely off the map to the north, is the county seat and the main commercial center. Active mining began in 1877 with the discovery of lead-zinc replacement ore bodies on Bayhorse Creek. Subsequent discoveries of other base-metal deposits and significant amounts of gold and silver led to extensive mining activity that waxed and waned over the years, but the mines in the area have never been completely inactive since the first discoveries. More recent discoveries and very extensive exploration and development within and immediately contiguous to the map area hold promise for significant new production of mineral commodities. Among the most promising of these are molybdenum, lead, zinc, silver, gold, and fluorspar.

Previous geologic studies that focused directly on the general geology of the Bayhorse area include those of Umpleby (1913), Ross (1934a, 1934b, 1937, 1962a, 1962b, 1962c), and Anderson (1954). Many workers contributed to the detailed studies that established the general understanding of the structural history. Early work in the Wood River region by Umpleby and others
(1930), in the Bayhorse region and Borah Peak quadrangle by Ross (1937, 1947), and in the Lost River Range by Baldwin (1951) recognized many of the major structures of the region and established a base on which subsequent workers have built a more detailed understanding (Tschanz and others, 1974; Dover, 1975, 1981; Hall and Batchelder, 1979; Hall and others, 1975; Skipp and Hall, 1975; Skipp and Hait, 1977; Batchelder and Hall, 1978; Hall and others, 1978; Ruppel, 1978, 1980, 1982; Ruppel and Lopez, 1981).

A restudy of the Bayhorse area was begun in 1964 by S.W. Hobbs and W.H. Hays and continued intermittently until 1982. D.H. McIntyre joined the study in 1971 and spent the period from then until 1981 on a detailed study of the Challis Volcanics. In addition to the mapping and description of numerous units of these volcanics shown on the map, McIntyre and others (1982) have published a general discussion of the volcanic field. W.H. Hays, who collaborated with all aspects of the work throughout the area, has been mainly responsible for the careful mapping and delineation of the middle and upper Paleozoic rocks of the Lone Pine Peak quadrangle and was coauthor of a series of detailed stratigraphic sections of these strata (Hays and others, 1980). An early report on this new work by Hobbs and others (1968) clarified the stratigraphic relations of the Ordovician Kinnikinic and related quartzites.

All of the rock units are described in abbreviated form in the section of this report entitled "Description of Map Units." Many of them are described in more detail in publications by Ross (1934a, 1937, 1962a, 1962c), Churkin (1963), Hobbs and others (1968), 
Mapel and others (1965), and McIntyre and others (1982). The following discussion focuses mainly on the general description and geologic evolution of the area; specific aspects of the geology, including the stratigraphy, are discussed only as necessary for an understanding and interpretation of the structural features and the development of the overall structural framework.

The names of many field assistants who provided much help during the course of the work are given in the mapping credits. Invaluable assistance and support were given by many colleagues of the U.S. Geological Survey who provided paleontological data, analytical services, and general counsel. These include R.J. Ross, Jr., Anita G. Harris, John W. Huddle, J.T. Dutro, Jr., and Leonard A. Wilson for paleontology; Richard F. Marvin for isotope dating; and Edward T. Ruppel, Wayne E. Hall, James H. Dover, and Tor H. Nilsen for general field consultation and advice.

\section{SUMMARY OF GEOLOGY}

The Bayhorse area includes the eastern part of the rugged Salmon River Mountains highland in its west half and the northern part of the east-central Idaho Basin and Range province in its east half. More than $10,700 \mathrm{~m}(35,000 \mathrm{ft})$ of predominantly marine strata of Paleozoic age or older occur within the map area. These strata were deformed by uplift and folding in the late Paleozoic and by one or more episodes of thrusting to the northeast during the late Paleozoic or early Mesozoic; steep normal faults displaced the allochthonous terranes in late Mesozoic and Tertiary times. A major north-northeast-trending structural break in the central part of the Bayhorse area, the Salmon River lineament, separates regions that are significantly different in lithology and structural style. The entire Bayhorse area is further subdivided into six structural-stratigraphic terranes, each of which is bounded by faults and marked by distinctive stratigraphic succession and structural patterns.

About half of this sedimentary sequence is overlain by erosional remnants of Eocene Challis Volcanics, which range in composition from basalt to rhyolite and comprise a sequence of flows, breccias, tuffaceous deposits, reworked tuffaceous sedimentary deposits, local vent complexes, intrusive bodies, and extensive ash-flow sheets mostly derived from sources outside the region to the west and north (McIntyre and others, 1982). The volcanics are cut by steep normal faults, mostly of moderate displacement. Major range-front faults of probable late Tertiary age in the Basin and Range province have large vertical displacement and have cut young alluvial fans during renewed movement in the Quaternary.

The eastern contact of the Idaho batholith is a few miles to the west, and several small intrusive bodies related to the batholith intrude the Paleozoic rocks in the Clayton quadrangle. Widespread alluvial fans, terrace gravels, colluvium, alluvium, landslides, and related deposits, all of Quaternary age, blanket major parts of the upland surfaces, intermontane basins, and stream valleys.

\section{TERRANES OF LATE PROTEROZOIC AND PALEOZOIC ROCKS}

For purposes of stratigraphic and structural description and analysis, the Bayhorse area has been divided into six structural-stratigraphic terranes that are identified on the accompanying map of structural blocks. Each of these terranes is generally bounded by major faults (commonly thrust faults), has a consistent internal structural style, and comprises rocks that differ in significant ways from those of other terranes. Although each of these terranes is an integral part of the geologic patchwork that makes up the whole, each shows a locally unique combination of geologic features that raises serious, and as yet unresolved, problems in relating one terrane to another and in the possible correlation of the geology with that of areas beyond the boundaries of the Bayhorse area.

Accurate determination of the original geographic and stratigraphic relations between some of these terranes presently appears to be beyond reach, but by describing and delimiting the components of each terrane we hope to define both our present knowledge and the remaining problems. The following discussion of the terranes will emphasize the major elements of the structure and stratigraphy.

\section{Terrane A}

Rocks of terrane A are exposed most extensively in the Challis 15-minute quadrangle, which adjoins the Lone Pine Peak quadrangle on the north (McIntyre and Hobbs, 1987). The few exposures of terrane $A$ in the northeast corner of the Bayhorse map area are quartzite members of a heterogeneous section of strata that probably underlies much of the Bayhorse area. 
Although the sequence is predominantly quartzitic, it contains subordinate dolomite interbeds, some thin argillite layers, and at least one thick argillite interval. The quartzite varies from deep red to dark purplish gray to medium gray and contains a few thick zones that vary from light pinkish or tannish gray to very light gray or white; medium grays and purplish grays predominate. Most of the quartzite part of the section is thin to medium bedded, platy, and laminated; some massive units are thick bedded and structureless. Grain size is mostly medium to fine, but locally the quartzite is coarse grained, pebbly, and includes coarse conglomerate or intraformational breccia. Much of the thin-bedded platy quartzite shows ripple marks, flute casts, worm trails, and locally abundant magnetite. The dolomite is very fine grained to dense, light to medium $\tan$ on fresh surface, and weathers to a rich, reddish tan or brown. The dolomite beds, which range from 0.2 to 2 $\mathrm{m}(0.6$ to $7 \mathrm{ft})$ in thickness, are interbedded with quartzite and are restricted to an area within $1 \mathrm{~km}(0.6$ mi) east from Beardsley Hot Springs (McIntyre and Hobbs, 1987). Argillite occurs as scattered laminae or thin interbeds in the quartzite and as at least one continuous interval about $100 \mathrm{~m} \mathrm{(330} \mathrm{ft)} \mathrm{thick.} \mathrm{It} \mathrm{is}$ generally thin bedded, fissile, and dark gray or purplish gray, and in places it is altered to deep grayish green. Much of the argillite is metamorphosed to phyllite close to thrust faults.

A definitive stratigraphic sequence is indeterminate because of complex structure and the discontinuity of exposures. General characteristics of the strata and the structural relations to the Middle Proterozoic Swauger Formation suggest a Late Proterozoic age or possible correlation with the Late Proterozoic(?) and Early Cambrian Wilbert and Ordovician Summerhouse Formations (Ruppel and others, 1975) or with Early Cambrian rocks in the southern Lemhi range that were described by McCandless (1982).

\section{Terrane B}

This terrane is an anticlinal structure of lower Paleozoic and older rocks exposed as a relatively small window through the thrust plate of terrane $\mathrm{D}$. It includes two small areas of outcrop, one along Squaw Creek in the west-central part of the Clayton quadrangle and another about $2 \mathrm{mi}$ to the northeast on Cash Creek. The intervening area is buried under Challis Volcanics.

The upper member of this stratigraphic pile is a medium- to thick-bedded, sandy and silty, light-colored dolomite (unit Occ) at least $150 \mathrm{~m}(500 \mathrm{ft}$ ) thick, whose age, based on poorly preserved fossils, is most probably Ordovician. It overlies unconformably a conformable sequence of strata more than $700 \mathrm{~m}(2,300 \mathrm{ft})$ thick that comprises Middle Cambrian shale and siltstone (unit $€ s)$ at the top, underlain by the Cash Creek Quartzite (unit $€ c$ ), a middle carbonate sequence (unit $€ c b$ ), and the quartzite of Boundary Creek (unit $€ b c$ ) at the base (Hobbs and others, 1968). None of these formations has been positively identified beyond the Bayhorse area, and the nearest possible correlatives are some of the units in the southern Lemhi Range that were described by McCandless (1982).

Several diverse structural features are important elements of terrane B. It is bounded at the top by a major thrust that brings quartzites of terrane $\mathrm{D}$ over the Ordovician carbonate of terrane B. Relations between the upper boundary thrust of terrane $B$ and the thrust at the base of the terrane $D$ allochthon where it is exposed east of the Kinnikinic Creek fault are ambiguous; strata above both thrusts are very similar, strata below are vastly different. Within terrane B the unconformity between the Ordovician carbonate and the lower Middle Cambrian siltstone documents uplift, steep faulting and planation of the Cambrian section before deposition of the Ordovician carbonate. The base of the quartzite of Boundary Creek is not exposed, but the lowest outcrops show much brecciation that may be related to a thrust not far below and that suggests that terrane B is bounded by thrusts at its base, as well as at its top, and is allochthonous.

Anticlinal folding followed the major thrusting of terrane D over terrane $B$ and produced the present configuration in which the thrust plate is folded nearly parallel to the bedding. The extension of this fold and the strata within it beyond the known exposures is completely masked by the overlying allochthons and the Challis Volcanics. Nearly on line to the south is the projected axis of the large anticlinal structure that is beautifully exposed along the Salmon River canyon between Kinnikinic Creek and Squaw Creek. This fold involves all strata of structural unit $D$ and may be related to the fold described above, but continuity with that fold is ambiguous.

\section{Terrane C}

Terrane $\mathrm{C}$ is a block of undated strata of probable Early Ordovician or Late Cambrian age that includes four lithologic units and in which the predominant structure is the broad Bayhorse anticline that trends 
northward across the central part of the Clayton quadrangle. Extension of this terrane beyond Mill Creek on the north and the Ziegler Basin quadrangle on the south is concealed by Challis Volcanics. No correlative strata or anticlinal structure have been found beyond the map area. On its west flank terrane $\mathrm{C}$ is bounded by the steeply dipping Kinnikinic Creek fault, which has dropped the Clayton Mine Quartzite of terrane D against the Ramshorn Slate of terrane $C$. The eastdipping east limb of terrane $C$ flattens into the valley of the Salmon River and is folded into a highly crumpled synclinorium, much of which is masked by scattered remnants of the terrane D allochthon. Both the Clayton Mine Quartzite of terrane D and the Ramshorn Slate of terrane $\mathrm{C}$ terminate eastward against the Salmon River lineament. The basal contact of terrane $\mathrm{C}$ is nowhere exposed, and the structural and stratigraphic relations of its lowest member to underlying rocks are unknown. Information from drill holes in the valley of Bayhorse Creek has delineated an intrusive porphyry body that generally parallels the bedding of the lower dolomite of terrane $\mathrm{C}$ and defines the lower limit of the terrane at this locality. A pattern of close relation between igneous intrusives and thrust faults, which has been documented at many places west and south of the Bayhorse area (Hall, 1985), together with the recognized allochthonous character of other terranes both above and below terrane $\mathrm{C}$, strongly suggests that terrane $\mathrm{C}$ also is allochthonous.

Strata within terrane C comprise, from top to bottom, the Ramshorn Slate (unit Or), Bayhorse Dolomite (unit O€b), and Garden Creek Phyllite (unit $\mathrm{Eg}$ ) of Ross (1934a), and the lower dolomite of Bayhorse Creek (unit $€ d$ ) that was subsequently discovered by Dooley P. Wheeler (oral commun., 1968). No one of these units is definitely dated, but small shell fragments from several localities in the Bayhorse Dolomite strongly suggest an Early Ordovician or possibly very Late Cambrian age, and this evidence is supported by the general stratigraphic sequence.

The four units that make up the $\mathrm{C}$ terrane total more than $1,525 \mathrm{~m}(5,000 \mathrm{ft})$ in thickness and, although generally conformable, include one major disconformity and several notable internal structural features. Most of the Ramshorn Slate has a very well developed slaty cleavage that imparts to the rock a deceptively simple false bedding. The origin of the pervasive cleavage is not clear, but much of it probably relates to adjustments of a thick, relatively incompetent shale (now the Ramshorn Slate) folded between competent Bayhorse Dolomite below and the Clayton Mine Quartzite of terrane $\mathrm{D}$ above. The bedding in the slate is deformed into irregular wavy folds and locally well developed isoclinal drag folds, all of which have well-developed axialplane cleavage that generally strikes parallel to the axial-plane of the main anticline. In the sandy and more competent upper and lower parts of the Ramshorn Slate, the cleavage is less well developed or absent. How much of the irregularity of bedding and the development of cleavage is related to the overriding thrust sheet of terrane D is uncertain, but the locally intense deformation immediately below the thrust commonly is parallel to the thrust plane. The complex internal structure of the unit precludes accurate measurement of thickness.

A major erosional disconformity separates the Ramshorn Slate from the underlying Bayhorse Dolomite. This break in the stratigraphic section is marked by a local, but very thick, channel conglomerate at the base of the Ramshorn, by erosion of an unknown thickness of Bayhorse Dolomite, and by the development of collapse breccias, cavern fillings, and other features related to a karst topography that was developed on the Bayhorse Dolomite before burial by the Ramshorn Slate. The structural and stratigraphic significance of this break in the depositional record is unknown.

As with the Ramshorn Slate, the Garden Creek Phyllite has developed the same, or even more intense, internal distortion by virtue of being folded between the massive, thick, competent beds of the Bayhorse Dolomite above and the lower dolomite of Bayhorse Creek beneath. The lower dolomite of Bayhorse Creek is barely exposed in very limited outcrops along the floor of Bayhorse Creek, and little is known of its structural pattern or original thickness.

Southward from the vicinity of Bayhorse Creek the sequence of strata in terrane $\mathrm{C}$ has been arched into a broad, generally symmetrical anticline; from Bayhorse Creek north the anticline is asymmetric with a gently dipping west limb and a more steeply dipping to vertical east limb in which the more competent and brittle Ramshorn conglomerate and Bayhorse Dolomite are locally fractured and brecciated.

None of the four formations that make up terrane C has been definitely identified outside the Bayhorse area, although Baldwin (1951), Ross (1937, 1947), and McCandless (1982) have suggested possible correlations of certain units in the Lost River Range and the southern part of the Lemhi Range with Ramshorn Slate, Bayhorse Dolomite, and Garden Creek Phyllite. 


\section{Terrane D}

Rocks of terrane $\mathrm{D}$ include units that differ widely in lithology and age, but which nonetheless make up a generally conformable sequence within a major allochthon whose upper contact is with the thrust sheet of terrane E, and whose lower, thrust-faulted, contact, wherever seen, is with the Ramshorn Slate of terrane C. At most places one or the other of the quartzite units of terrane D-2 (see map of structural blocks) forms the base of the allochthon, but the most favored horizon for movement is the interbedded siltstone and quartzite unit (unit Osq) that underlies the Clayton Mine Quartzite. This plane of movement, although very accurately located over most of its extent, cannot be identified with any assurance north of Bayhorse Creek, where it can be interpreted either to have become dispersed in the underlying Ramshorn Slate or to have cut up section across the Clayton Mine Quartzite and to have been offset by the Kinnikinic Creek fault. A strong west-northwest-trending sheared zone in the quartzite north of Bayhorse Lake suggests the second interpretation. Erosional remnants of terrane D are widely scattered over the Bayhorse area west of the Salmon River lineament.

Two contrasting groups of strata are identified within terrane $D$. The first group (D-1) constitutes the upper part of the sequence and includes the Middle and Late Ordovician Saturday Mountain Formation, the Middle Ordovician Kinnikinic Quartzite, and the Middle Ordovician Ella Dolomite. These are all dependably dated formations that have their type localities within the area (Ross, 1937; Hobbs and others, 1968). Both the Saturday Mountain Formation and the Kinnikinic Quartzite have correlative units far to the east and south of the Bayhorse region that attest to their widespread distribution (Ross, 1934a, 1962a; Ruppel, 1968; Dover and R.J. Ross, Jr., 1975; James and Oaks, 1977; Oaks and James, 1980). Other less well known carbonate strata in the southern Lemhi Range have been proposed as possible correlatives of the Ella Dolomite (McCandless, 1982), and scattered roof pendants of metamorphosed calcareous and quartzitic rocks in the Idaho batholith to the west and the south of the map area are considered to be detached parts of these same formations.

The lower part of this terrane (D-2) lies disconformably below the formations of carbonate and mature quartzite described above and comprises more

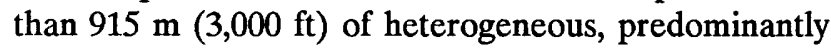
quartzitic strata that are probably parts of at least two, and possibly more, separate stratigraphic sequences that have been juxtaposed by a combination of thrusting and subsequent normal faulting during the complex structural history of the area. The thickest and most widespread sequence, made up of the Clayton Mine Quartzite (unit Oc) and the closely related underlying mixed lithology sequence (unit Osq), can be traced or correlated with a fair degree of certainty from its type locality in the southwestern part of the Clayton quadrangle over much of the west half of the map area (Hobbs and others, 1968). One or the other of these two units directly overlies the thrust fault that can be identified beneath many of the erosional remnants of terrane $\mathrm{D}$.

Two other quartzite units (Och, Osp) that are included in terrane $\mathrm{D}$ are probably related to either the Clayton Mine Quartzite or the mixed lithology sequence but were delineated on the main map because of lithologic differences and structural isolation. The quartzite sequence on upper Cash Creek and a small outcrop west of Squaw Creek opposite the mouth of Cash Creek (unit $\mathrm{O} € q$ ) has many of the attributes of the Clayton Mine Quartzite, but pronounced differences in lithology and structure preclude definite correlation. Most of this quartzite is medium to thin bedded and contains thin interbeds of siltstone and one siltstone interval at least $90 \mathrm{~m} \mathrm{(300} \mathrm{ft)} \mathrm{thick.} \mathrm{Feldspar} \mathrm{is}$ abundant, and much of it is very coarse. This quartzite sequence is floored by a major thrust fault that is folded into a broad antiform; the quartzite is thrust across Ordovician carbonate at the exposures in upper Cash Creek, and across Middle Cambrian shale at the exposures west of Squaw Creek. The relation of this thrust to the well-exposed one that underlies the Clayton Mine Quartzite or the one beneath the Rob Roy sequence (unit O€rr) is not clearly defined.

The Clayton Mine Quartzite of Happy Hollow (unit Och) is similar in many aspects to the type Clayton Mine Quartzite, but is generally more massive, lighter colored, and cleaner in that it contains less feldspar. The prong of Clayton Mine Quartzite that projects into the $\mathrm{B}$ terrane is interpreted as a fault slice whose geometry and origin are not known. A more questionable correlative unit of the Clayton Mine Quartzite is a sequence that is informally called the "siltstone, sandy siltstone, and quartzite of the Rob Roy mine area" (unit OErr). These strata comprise a thick heterogeneous sequence of various quartzites, siltstones, and, in the lower half, scattered beds of pure dolomite. They occupy a graben with steep bounding faults on the east and west sides and are floored by a flat fault, probably a 
major thrust, that has brought this sequence over the Ella Dolomite. The flat fault is exposed for a short distance in the cliff face about $460 \mathrm{~m}(1,500 \mathrm{ft})$ north of the Clayton silver mine. Its continuity has been confirmed by drill-hole data from the Rob Roy mine, nearly $1 \mathrm{mi}$ north of the outcrop. The quartzite and siltstone within the graben have been folded into a major asymmetrical anticline having a steeply overturned wrinkle on the eastern limb. Extensions of the graben and the rocks within it are concealed for several miles at its northern end by Challis Volcanics, and its lithologies do not match those of the quartzite exposures beyond the covered interval (unit $O \in q$ on the map).

Interbedded siltstone, quartzite, and dolomite of upper Sawmill Creek and Poverty Flat (unit Osp) is a heterogeneous sequence that has some of the characteristics of the mixed lithology sequence (unit Osq) that underlies the Clayton Mine Quartzite. It also has affinities with the siltstone, sandy siltstone, and quartzite of the Rob Roy mine area (unit OErr). No evidence for satisfactory correlation with either of the above units has been found.

The allochthon that forms the $\mathrm{D}$ terrane is folded in general conformity with the major folds of the underlying $\mathrm{C}$ and $\mathrm{B}$ terranes. In detail, however, the strata within the allochthon are locally more intensely folded and deformed. The east limb of the Clayton anticline, where exposed west of lowermost Kinnikinic Creek, is vertical and adjoins, east of the creek, the gently dipping or nearly flat quartzite of the west limb of another terrane D fold that arches over the Bayhorse anticline. A north-trending zone of steep faulting, the Kinnikinic Creek fault, cuts out the trough of the intervening syncline. At a distance of $8 \mathrm{~km}(5 \mathrm{mi})$ to the east, much of the Clayton Mine Quartzite along or near the east edge of the known extent of the terrane $D$ thrust plate is intensely deformed by small tight folds, vertical wavy bedding, and recumbent isoclinal folds. These structures, which are west of, but parallel to, the Salmon River lineament are well displayed along the Salmon River from the mouth of the East Fork nearly to Challis.

A disconformity within the $D$ terrane between the Ella Dolomite and the Clayton Mine Quartzite represents an unknown time interval, but is marked by a sharp, drastic change in depositional regimes and by an apparent low-angle unconformity. At its type section, the upper member of the Clayton Mine Quartzite, where in contact with the overlying Ella Dolomite, is a thick section of conglomeratic quartzite containing abundant feldspar. On Germer Peak, $19 \mathrm{~km}$ (12 mi) to the northeast, more than $120 \mathrm{~m}$ (400 ft) of medium- to fine-grained, feldspar-free, nearly pure quartzite overlies the conglomerate horizon and forms the upper member of a locally very thick Clayton Mine Quartzite sequence. Even though rapid facies changes are expectable in strata like the Clayton Mine Quartzite, the relations at its top suggest a depositional break and interval of erosion.

The Clayton Mine Quartzite has been identified beyond the map boundaries only in the central Pioneer Mountains about $65 \mathrm{~km}(40 \mathrm{mi})$ to the south-southwest (Dover, 1981). Possibly the Wilbert Formation, as described in the southern Lemhi Range by Ruppel and others (1975), and as further described by McCandless (1982), may be correlative with some facies of the Clayton Mine Quartzite, but direct evidence is lacking. The D allochthon appears to terminate eastward at the Salmon River lineament, and this boundary may represent the west edge of a pre-thrust uplifted block that the allochthon stalled against or overrode. No extension of this thrust plate has been identified east of the lineament.

\section{Terrane E}

Strata of this terrane in the southwest corner of the Clayton quadrangle are but a very small part of an extensive allochthon of the Salmon River assemblage (Hall, 1985). This unit, originally named the "Salmon River sequence" by Nilsen (1977), is a tectono-stratigraphic mixture of Late Cambrian, Late Devonian, and Late Mississippian strata that has been thrust over the Ordovician units of terrane D. The Salmon River assemblage comprises generally dark gray to nearly black carbonaceous argillite, calcareous siltstone, siltstone, turbidites, and lesser amounts of fine-grained quartzite and relatively pure limestone. Much of the sequence is thin to medium bedded and contains interlaminated argillite, siltstone, and fine-grained, mediumbrown sandstone that shows small-scale current structures, sole markings, and local soft-sediment deformation. The unit extends westward and southward, where it is intruded by the Idaho batholith, overlapped by higher thrust plates of Pennsylvanian and Permian strata, or covered by Challis Volcanics (Hall, 1985).

Most of the beds dip steeply to the west, and in general are younger to the east with much evidence of overturning. The internal structure, however, is very complex, and the great apparent thickness exposed westward from the map region can probably be explained by major isoclinal folding, internal thrusting, 
and much duplication of the section that has not yet been defined.

The basal thrust, which marks the eastern limit of this terrane, is easily traced from its northernmost exposure on upper Bruno Creek to Pine Creek on the south; terrane $E$ is everywhere thrust faulted across Upper and Middle Ordovician carbonate units of terrane D or Ordovician black shale in the Pine Creek area. The thrust fault plane is marked in many places by massive ledges of black silicified argillite, chert, brecciated argillite, or well-developed slickensided surfaces. Locally, where the thrust is parallel to the bedding, the trace is less well defined. Along the lower reaches of Squaw Creek and Sullivan Creek, younger northtrending steep faults displace the thrust plate.

Rocks of this terrane have much in common with the Copper Basin Formation of Ross (1962b, 1962c), but include strata that range in age from Cambrian to Upper Mississippian and thus contrast with the type Copper Basin Formation of Lower Mississippian age.

\section{Terrane F}

This terrane is but a small part of the very extensive east-central Idaho Basin and Range province. The strata are largely of middle and late Paleozoic age, are dominantly carbonate, and represent parts of the stratigraphic sections that are mostly absent in the terranes to the west, from which they are separated by the Salmon River lineament. The stratigraphic section exposed here is generally younger and better known than that to the west; it is an extension of the stratigraphy studied by Ross (1947) and by Mapel and others (1965) in the Lost River Range and by other workers along the border of Idaho and southwestern Montana. Geology of this terrane differs from that in the others in three significant ways: different facies and ages of the strata, structural style, and regional trends.

Both the Saturday Mountain Formation and the Kinnikinic Quartzite, which have their type sections in terrane $D-1$, are represented in terrane $F$ by significantly different facies and thicknesses. The implication of these differences is discussed in the sections on the Salmon River lineament and on regional structure. Above the Saturday Mountain Formation in terrane F, the Paleozoic section comprises the Roberts Mountains Formation (unit Srm) and Laketown Dolomite (unit SI) of Silurian age, the Beartooth Butte Formation and overlying unnamed dolomite units (units $\mathrm{Dab}, \mathrm{Db}$ ), the Jefferson Dolomite (unit Dj), Grand View Dolomite (unit Dg), and Three Forks Formation (unit Dtf), all of
Devonian age, and the McGowan Creek (unit Mmg), Middle Canyon (unit Mmc), and Scott Peak Formations (unit Msp) of Mississippian age.

A lower Tertiary fanglomerate of local derivation is known in a few places to separate the surface that was eroded across the folded Paleozoic strata from the overlying Eocene volcanics.

The structural pattern of terrane $F$, although containing many elements of the prevailing patterns in terranes E, D, and C, is dominated by an extensional regime of post-Eocene age that produced well-developed block-fault ranges separated by wide intermontane basins. Early folding, thrust faulting, and steep normal faulting, although undoubtedly related to similar structures west of the Salmon River lineament, are generally less intense. Regional trends expressed in the general $\mathrm{N} .30^{\circ} \mathrm{W}$. orientation of the basins and ranges, as well as similar trends of internal structures in the major fault blocks, are distinctly askew to the predominant northerly trends of fold axes and steep faults of the other terranes. A major anticline-syncline pair of folds in the west-central part of terrane $F$ forms the crest and east flank of Lone Pine Peak ridge, where steeply dipping rocks and overturned folds are cut off by nearly parallel range-front faults that bound the east side of the range. The significance of this steep folding is not known, but the eastward vergence could suggest a major thrust fault below Lone Pine Peak that is now concealed under the basin-fill debris east of the rangefront fault. Tight folding and complex faulting in the northern part of the Lost River Range, along the east border of the Bayhorse map area, may also reflect the disruption of thrust faults and related folds by major range-front faults. In the Doublespring quadrangle, east of the Bayhorse region, thrust sheets are cut by steep normal faults of late Mesozoic or Tertiary age (Mapel and others, 1965). These faults, however, follow the northwesterly trend that characterizes most all structures in the $\mathrm{F}$ terrane.

\section{Summary}

The six terranes described above include strata of widely diverse source areas, environments of deposition, and, to some extent, structural style. Each one is bounded by major structures that either are thrust faults or are a combination of thrust faults and steeply dipping faults. The steeply dipping faults, mainly of normal displacement, are a part of an extensive period of steep faulting that followed folding and thrusting. Most of the steep faults west of the Salmon River 
lineament trend north; those east of the lineament trend northwest. In addition to the Salmon River lineament, which clearly is of regional significance, the Kinnikinic Creek fault zone separates two major antiforms, and represents a major structural break that has been projected northward beneath the Challis Volcanics. The straight unfaulted contact between the volcanics and the Clayton Mine Quartzite in the north half of the Clayton quadrangle is probably a buried fault-line scarp along the extension of the Kinnikinic Creek fault zone.

Even though terranes C, B, and F have no exposed basal thrust faults, studies in other areas provide strong evidence that all Precambrian through Lower Mississippian rocks in the Bayhorse area are allochthonous. The juxtaposition of terranes consisting of locally unique rock sequences reflects a very complex structural intermixing of diverse rocks that were transported for unknown distances and are, in part, different facies of the same formation.

\section{THE SALMON RIVER LINEAMENT}

A major fault or fault zone, the Salmon River lineament, forms the boundary between terrane $F$ and terranes D and C immediately to the west of it. In the context of the stratigraphic and structural complexity of the pre-Tertiary rocks on both sides of the lineament, it stands out as a consistent, linear structural and stratigraphic boundary, and the striking differences in structural trends, deformation, and stratigraphic facies across the lineament are strong evidence of its regional significance. In most places it is poorly exposed and illdefined and so is termed a lineament. It can be closely identified only in exposures east of Germer Peak, in the north-central part of the map area, where, for a distance of about $1.6 \mathrm{~km}(1 \mathrm{mi})$, a north-northeasttrending zone of complex faulting separates strata that are characteristic of terrane $D$ from those of terrane $F$. Farther north and south the zone is buried by Challis Volcanics and Quaternary deposits. A highly contorted and recumbently folded section of Silurian strata exposed in Spar Canyon, about $1 \mathrm{mi}$ above its junction with the East Fork of the Salmon River, is an integral part of terrane $F$, and is interpreted to be related to deformation associated with vertical movement on steeply dipping structures of the Salmon River lineament, which must lie in the covered area a short distance to the west. The recumbent fold is interpreted to be in the footwall of the overriding $D$ terrane that has been eroded from the region east of the lineament.

Of the differences that distinguish the geology on opposite sides of the lineament, those in stratigraphic sequences provide the most compelling evidence for the significance of this structure. The heterogeneous Ordovician and older lithologies west of the lineament contrast markedly with the very thick and predominantly carbonate Silurian and Devonian section on the east side. The Saturday Mountain Formation and the Kinnikinic Quartzite are present as a part of the stratigraphic section both to the east and the west of the Salmon River lineament, but major facies changes occur within these units across the lineament. West of the lineament the Kinnikinic Quartzite, although folded and faulted, has been estimated to be between 150 and $245 \mathrm{~m}$ (500 and $800 \mathrm{ft}$ ) thick. It contains partings and interbeds of black shale and siltstone, anomalous irregularities in bedding and grain size, and impurities that impart an uncharacteristicly dark color to much of the unit (James and Oaks, 1977; Oaks and James, 1980). East of the lineament, the Kinnikinic Quartzite also is structurally disturbed, but it is significantly thicker, more massive, and contains little or no shale component or dark impurities. The Saturday Mountain Formation shows an even more striking contrast both in composition and in thickness. The western facies of the Saturday Mountain is massive dolomite, sandy dolomite, silty limestone, calcareous siltstone, black shale, and a few beds of dolomitic quartzite as much as

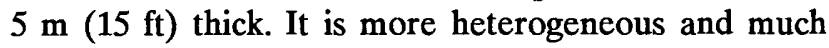
thicker than the eastern section, which spans the same age range, and is relatively pure, medium- to thinbedded dolomite. The total thickness of the Saturday Mountain Formation in the vicinity of Squaw Creek west of the Salmon River lineament is estimated to be about $915 \mathrm{~m}$ (3,000 ft); less than $305 \mathrm{~m}(1,000 \mathrm{ft})$ occurs on the east side of the lineament. These major facies changes within a distance of less than $16 \mathrm{~km}(10 \mathrm{mi})$, taken together with the marked structural contrasts described above, show clearly that the Salmon River lineament is a major tectonic feature in the Bayhorse area.

The juxtaposition of very different facies of both lower Paleozoic and Late Proterozoic strata along the Salmon River lineament is related to a complex regional geologic history that is only partly understood. Terrane D allochthon comprises strata of a cratonic margin or western facies environment that were thrust eastward during the early Mesozoic for an unknown distance over the eastern facies rocks of terrane $F$. Steep normal faults of late Mesozoic or early Tertiary 
age displaced the thrust plates, and one of these faults, along the line of the Salmon River lineament, displaced western facies strata of terrane $D$ against the eastern facies rocks of terrane $F$.

\section{PRE-TERTIARY INTRUSIVE ROCKS}

Pre-Tertiary intrusive rocks in the Bayhorse region are limited to several small stocks of quartz monzonite and granodiorite, and widely scattered dikes, sills, and plugs of gabbro. The most prominent of these is the quartz monzonite Juliette stock, which crops out over an area of about $1.3 \mathrm{~km}^{2}\left(0.5 \mathrm{mi}^{2}\right)$ near the middle of the Clayton quadrangle. Several smaller satellite bodies occur to the north and south of the main stock, and this cluster of intrusives produces a conspicuous metamorphic aureole in the enclosing Ramshorn Slate. Two small bodies of similar composition intrude the Ordovician Saturday Mountain Formation and the Cambrian to Mississippian Salmon River assemblage along or very near the thrust fault that separates the $E$ and $D$ terranes along upper Bruno Creek. Numerous other small igneous bodies of similar composition occur in the Thompson Creek and Sunbeam quadrangles west of the Bayhorse map area, and all of them are undoubtedly related to the main mass of the Idaho batholith, whose eastern border is less than $9 \mathrm{~km}(6 \mathrm{mi})$ away. The age of $98.1 \pm 3.3$ m.y. for the Juliette stock (McIntyre and others, 1976) is older than ages for the central part of the main batholith.

Gabbro intrusives, widely distributed across the central part of the Clayton quadrangle, are darkgrayish-green, coarse-grained rocks whose original gabbroic composition has been overprinted by pervasive alteration that precludes detailed description and reliable age dating. They occur for the most part as dikes, sills, plugs, and irregular bodies that range widely in size but may be as much as $75 \mathrm{~m}(250 \mathrm{ft})$ thick and more than $1.6 \mathrm{~km}(1 \mathrm{mi})$ long. Most of the gabbro intrusives are either localized within the thrust zone between terranes $C$ and D, like the occurrences on both sides of the Salmon River near the junction of the East Fork, or are in the Ramshorn Slate close below the fault plane, like the occurrences along the east side of Kinnikinic Creek and at the north end of Poverty Flat. Several other small gabbro intrusives are localized close to this thrust zone around the northern periphery of terrane C. In a few places gabbro has intruded for a short distance into the overlying quartzites of terrane D. The intrusive relations of the gabbro consistently suggest that it is younger than the thrust faulting that carried terrane $\mathrm{D}$ over terrane $\mathrm{C}$.

The age of the gabbro is of critical importance in establishing the age of thrust faulting in east-central Idaho. Direct dating of the rock has been difficult because of the pervasive alteration that has destroyed all original minerals. Fortunately, an intrusive contact of gabbro and Clayton Mine Quartzite is well exposed on a small knob of terrane D that projects through the surrounding Challis Volcanics near the mouth of Bayhorse Creek. A fission-track age of $140.1 \pm 17.4 \mathrm{~m} . \mathrm{y}$. was obtained from zircon in the quartzite immediately adjacent to the contact with gabbro (R.A. Zimmermann, written commun., 1983). This age for the zircon indicates the time of track annealing caused by heat from the gabbro intrusion. It also serves as a limiting age for the thrust fault beneath terrane $D$ that was already in existence prior to intrusion of the gabbro. This age, which is considered to be reasonably reliable, is critical in relating the earliest thrusting in central Idaho to much younger thrusting farther east in Montana.

\section{CHALLIS VOLCANICS}

Challis Volcanics of Eocene age cover nearly onehalf of the Bayhorse area and are the erosional remnants of a widespread volcanic sequence that buried the entire region. The presence of volcanic deposits on the highest levels, as well as in the deepest canyons, where they are commonly found chilled against the preTertiary formations, strongly suggests extrusion over an area whose relief was comparable to the one seen today.

These volcanic rocks are a heterogeneous, overlapping and interfingering sequence of extrusive lavas, breccias, and tuffaceous material that includes extensive ash-flow sheets and water-laid tuffaceous sediments. Numerous local intrusive centers comprising breccia pipes, domes, sills, and local flows or flattened domes of related extrusive material add to the complexity of the sequence. Composition of the varicus units ranges from olivine basalt and intermediate mafic lavas to andesite, latite, rhyodacite, and rhyolite. Localization of the extrusive volcanic materials was controlled in many places by the rugged pre-volcanic topography, and, as a result, the correlation of units between separated deposits has been difficult. The great variety of rock types in the Challis Volcanics and their origin is summarized in the description of map units. More 
discussion of the Challis volcanic complex is given by McIntyre and others (1982).

Folds in the Challis Volcanics are generally open and gentle; dips rarely exceed $30^{\circ}$, and in much of the area the bedding is nearly horizontal. Minor irregularities are in many places related to differential compaction of the tuffaceous members. In addition, the Challis is cut by numerous steeply dipping faults that have relatively modest stratigraphic displacement. Many of these faults express renewed movement on pre-Tertiary structures in the underlying Paleozoic rocks. Others, usually of more random orientation, are related to adjustments within the volcanic pile after its deposition.

Local areas of deformation are attributed to intrusion of magma as domes, laccoliths, and sills. Block faulting and the generation of basin and range structures in the eastern part of the map area have produced regional tilting of volcanic rocks both in the basins and on the crests of several of the ranges and highland areas.

\section{QUATERNARY DEPOSITS}

Thirteen mappable units ranging in age from late Pleistocene to Holocene mantle about one-fourth of the land surface of the Bayhorse area. The two most widely spread of these units are old alluvial-fan deposits (unit Qfo) and debris of landslide origin (unit Ql). Most of the older fans cover a large part of Antelope Flat, Warm Spring Creek Valley, and Round Valley, in the Lone Pine Peak quadrangle, and the broad intermontane basin between Lone Pine Peak ridge and the north end of the Lost River Range, from which the fans were derived. Scattered outcrops of Paleozoic rocks at various places across the floor of this basin, as well as extensive areas of Tertiary Challis Volcanics, indicate, however, that such Quaternary fill in this part of the graben is relatively thin. Landslide deposits are scattered more widely across the Bayhorse region and are most numerous on the tuffaceous rocks of the Challis Volcanics, which become highly mobile as earthslides and mudflows when water saturated. The fissile Ramshorn Slate, which weathers into small chips and plates, has produced numerous landslides and rock glaciers. Younger alluvial fans (unit Qfy), snow avalanche deposits (unit Qla), mudflows (unit Qm), and large slump blocks of essentially unbroken strata (unit Qs) also are present in many places. In some areas extensive colluvium forms a weathered residue that buries the underlying bedrock.

All of the main valleys and many of the minor ones are floored with alluvial deposits (unit Qal) that include not only the present flood plain but also several levels of terrace gravels. Gravel-capped terraces cut on bedrock and local fill terraces are very prominent along the Salmon River and its main tributaries. In a few places, deposits of the oldest of these gravels are large enough to be mapped separately (unit Qgo).

Deposits of possible glacial origin are restricted to the upper reaches of Mill Creek, where deposits of unsorted gravels (units Qd and Qsu) are probably remnants of old till. North of Daugherty Gulch an extensive area of solifluction debris may reflect a periglacial environment. The morphology of a few valley heads on the east side of Poverty Flat and at a few north-facing slopes above Bayhorse Creek and Garden Creek suggests the former presence of small glaciers, but no true cirques were formed or tills deposited.

\section{STRUCTURAL HISTORY}

A long, complex, and locally very intense structural history that extends back into the Precambrian has been documented for much of the region that includes and surrounds the Bayhorse area. Evidence for Middle Proterozoic plutonism has been found in the Salmon, Idaho, area to the north (Evans and Zartman, 1981a), and for major tectonism in the Lemhi Range, to the east, where lower Paleozoic rocks overlie unconformably faulted and folded Middle Proterozoic strata (Ruppel, 1968). The regional relations of Proterozoic and basal Paleozoic rocks indicate at least two episodes of major deformation in Proterozoic time.

Although the Early Paleozoic has long been considered to have had a relatively stable miogeosynclinal depositional regime, data are accumulating that point toward a mid-Ordovician disturbance that may have been widespread. Several radiometric ages confirm Ordovician plutonism in the Salmon River and Beaverhead Mountains (Ruppel, 1968; Scholten and Ramspott, 1968; Evans and Zartman, 1981b), and geologic evidence from the same general area documents syndepositional faulting of Ordovician strata (Garmezy and Scholten, 1981). The erosional disconformities between rock units in terranes $\mathrm{C}$ and $\mathrm{B}$ probably are manifestations of this event.

The Late Devonian to Early Mississippian Antler orogeny, documented in Nevada, extended into central 
Idaho, where certain phases of it may have culminated somewhat later than to the south. Extensive Mississippian synorogenic detrital deposits derived from the Antler highland covered large areas of south-central Idaho (Sandberg, 1975; Nilsen, 1977; Poole and Sandberg, 1977; Skipp and others, 1979; Dover, 1980). Eastward thrust faulting may have accompanied the Antler orogenic episode, but no thrust faults specifically related to it have been identified in central Idaho (Paull, 1976; Skipp and others, 1979; Dover, 1980). Some of the open folds in lower Paleozoic strata may have been formed during the Antler orogeny.

In Middle Pennsylvanian and Early Permian time, parts of the great pile of Mississippian flysch deposits were uplifted to form a highland area that became the source for detritis shed into basins to the east and west. For the most part, south-central Idaho was a positive, but probably low-lying, area subject to nondeposition and erosion from Late Permian into the Early Triassic.

The Sevier orogeny, which may have begun as early as late Jurassic, culminated in major folding, thrust faulting, intrusion of various phases of the Idaho batholith, and general uplift of central Idaho in latest Cretaceous or the Paleocene. During this orogeny, most, if not all, of the great thrust sheets of southcentral and east-central Idaho were emplaced. These include the basal Medicine Lodge thrust, or décollement (Ruppel, 1978), which involves major units of the Proterozoic, and a series of allochthons of successively younger strata that terminate with the Permian rocks of the Grand Prize Formation (Hall, 1985). The western part of the stack of Sevier allochthons was intruded by the plutonic rocks of the Idaho batholith during middle and Late Cretaceous time. Steep normal or strike-slip faults were developed following relaxation of compressional forces and were accompanied by regional uplift and the igneous intrusion.

Erosion of the highland area of central Idaho reached an early mature stage of dissection by the early Eocene, and this rugged terrane was subsequently buried by the Eocene Challis Volcanics. Renewed activity on the pre-Challis steep faults and the development of new post-volcanic faults have displaced the volcanic units by different amounts. Many of the faults shown within the major areas of volcanic rocks have moderate displacement; those along the borders of major fault blocks may displace the volcanic section for many thousands of feet.

A tectonically quiet period during the Oligocene and early Miocene (Christiansen and McKee, 1978) was followed by major basin-and-range extensional faulting that was developed mainly in east-central Idaho and that part of the Bayhorse area east of the Salmon River lineament. Some of these range-front faults have been active into the Holocene (Hait and Scott, 1978).

Many of the problems that relate to the stratigraphic record and the long structural history are as yet unresolved, and critical gaps in our knowledge may never be filled. We are hopeful that the ages of the numerous undated rock units will be determined from new fossil evidence or through the use of new or refined techniques. Such information will aid in the correlation of isolated lithologies within the study area, and, more importantly, with well-established units far beyond. The geographic origins of most formations in terranes B, C, and $D$ are indeterminate or hopelessly complicated by extensive thrusting, by post-thrust steep normal faults, by the wide-spread cover of Challis Volcanics, and by the intrusion of the Idaho batholith and associated plutons. Basins of deposition and the accompanying source terranes for these strata can only be surmised. A further complicating factor is the compelling evidence from the Lemhi Range and Beaverhead Mountains, far to the east of the Bayhorse area (Ruppel, 1978), that a deep-seated decollement may underlie the entire Bayhorse region and that all Paleozoic, and probably most Proterozoic, rocks have been transported an indeterminate distance to the east. The confirmation of this concept in the Bayhorse area and its relation to the above-mentioned problems and to the origin and evolution of the Salmon River lineament are of fundamental importance.

\section{REFERENCES CITED}

Anderson, A.L., 1954, A preliminary report on the fluorspar mineralization near Challis, Custer County, Idaho: Idaho Bureau of Mines and Geology Pamphlet 101, 12 p.

Armstrong, R.L., 1975, The geochronometry of Idaho: Isochron/West, no. 14, p. 1-50.

Baldwin, E.M., 1951, Faulting in the Lost River Range of Idaho: American Journal of Science, v. 249, no. 12, p. 884-902.

Batchelder, J.N., and Hall, W.E., 1978, Preliminary geologic map of the Hailey 7 1/2-minute quadrangle, Idaho: U.S. Geological Survey OpenFile Report 78-546, scale 1:24,000.

Christiansen, R.L., and McKee, E.H., 1978, Late Cenozoic volcanic and tectonic evolution of the Great Basin and Columbia intermontane regions, 
in Cenozoic tectonics and regional geophysics of the western Cordillera: Geological Society of America Memoir 152, p. 283-312.

Churkin, Michael, Jr., 1963, Ordovician trilobites from graptolitic shale in central Idaho: Journal of Paleontology, v. 37, p. 421-428, pl. 51.

Dover, J.H., 1975, Character and tectonic development of the Sevier orogenic belt in the northern Pioneer Mountains, central Idaho [abs.]: Geological Society of America Abstracts with Programs, v. 7, no. 7, p. 1333-1334.

1980, Status of the Antler orogeny in central Idaho-Clarifications and constraints from the Pioneer Mountains, in Fouch, T.D., and Magathan, E.R., eds., Paleozoic paleogeography of the westcentral United States: Society of Economic Paleontologists and Mineralogists, Rocky Mountains Section, West-central United States Paleogeography Symposium 1, 1980, p. 371-386.

1981, Geology of the Boulder-Pioneer Wilderness Study Area, Blaine and Custer Counties, Idaho, in U.S. Geological Survey and U.S. Bureau of Mines, Mineral resources of the Boulder-Pioneer Wilderness Study Area, Blaine and Custer Counties, Idaho: U.S. Geological Survey Bulletin 1497-A, p. A15-A75.

Dover, J.H., Berry, W.B.N., and Ross, R.J., Jr., 1980, Ordovician and Silurian Phi Kappa and Trail Creek Formations, Pioneer Mountains, Central IdahoStratigraphic and structural revisions, and new data on graptolite faunas: U.S. Geological Survey Professional Paper 1090, $54 \mathrm{p}$.

Dover, J.H., and Ross, R.J., Jr., 1975, Ordovician and Middle Silurian rocks of the Wildhorse window, northeastern Pioneer Mountains, central Idaho: U.S. Geological Survey Journal of Research, v. 3, no. 4, p. 431-436.

Evans, K.V., and Zartman, R.E., 1981a, U-TH-Pb zircon geochronology of Proterozoic $\mathrm{Y}$ granitic intrusions in the Salmon area, east-central Idaho [abs.]: Geological Society of America Abstracts with Programs, v. 13, no. 4, p. 195.

1981b, Evidence from U-Th-Pb zircon ages for Cambrian-Ordovician plutonism in east-central Idaho [abs.]: Geological Society of America Abstracts with Programs, v. 13, no. 4, p. 195.

Garmezy, Lawrence, and Scholten, Robert, 1981, Multiple deformation in a portion of the fold and thrust belt, southern Beaverhead Mountains, eastcentral Idaho [abs.]: Geological Society of America Abstracts with Programs, v. 13, no. 4, p. 198.
Hait, M.H., Jr., and Scott, W.E., 1978, Holocene faulting, Lost River Range, Idaho [abs.]: Geological Society of America Abstracts with Programs, v. 10, no. 5 , p. 217.

Hall, W.E., 1985 [1986], Stratigraphy of and mineral deposits in Middle and Upper Paleozoic rocks of the black-shale mineral belt, central Idaho, in Symposium on the geology and mineral deposits of the Challis $1^{\circ} \times 2^{\circ}$ quadrangle, Idaho: U.S. Geological Survey Bulletin 1658-A-S, p. 117-131.

Hall, W.E., and Batchelder, J.N., 1979, Preliminary map of the Baugh Creek Southwest 7 1/2-minute quadrangle, Idaho: U.S. Geological Survey OpenFile Report 79-1617, scale 1:24,000.

Hall, W.E., Batchelder, J.N., and Skipp, Betty, 1975, Structural evolution of the Milligen and Wood River allochthons, south-central Idaho [abs.]: Geological Society of America Abstracts with Programs, v. 7, no. 5, p. 611-612.

Hall, W.E., Batchelder, J.N., and Tschanz, C.M., 1978, Preliminary geologic map of the Sun Valley $71 / 2$ minute quadrangle, Idaho: U.S. Geological Survey Open-File Report 78-1058, scale 1:24,000.

Hays, W.H., Harris, A.G., Dutro, J.T., Jr., and Ross, R.J., Jr., 1980, Stratigraphic sections of Middle Paleozoic rocks in the vicinity of Spar Canyon, Custer County, Idaho: U.S. Geological Survey Open-File Report 80-1097.

Hobbs, S.W., Hays, W.H., and Ross, R.J., Jr., 1968, The Kinnikinic Quartzite of central Idaho-Redefinition and subdivision: U.S. Geological Survey Bulletin 1254-J, p. J1-J22.

James, W.C., and Oaks, R.Q., Jr., 1977, Petrology of the Kinnikinic Quartzite (Middle Ordovician), eastcentral Idaho: Journal of Sedimentary Petrology, v. 47, no. 4, p. 1491-1511.

Mapel, W.J., Read, W.H., and Smith, R.K., 1965, Geologic map and sections of the Doublespring quadrangle, Custer and Lemhi Counties, Idaho: U.S. Geological Survey Geologic Quadrangle Map GQ-464, scale 1:62,500.

Marvin R.F., and Dobson, S.W., 1979, Radiometric ages-Compilation B, U.S. Geological Survey: Isochron/West, no. 26, p. 3-32.

McCandless, D.O., 1982, A re-evaluation of Cambrian through Middle Ordovician stratigraphy of the southern Lemhi Range: University Park, Pennsylvania State University, M.S. thesis, 157 p.

McIntyre, D.H., Ekren, E.B., and Hardyman, R.F., 1982 [1984], Stratigraphic and structural framework of the Challis Volcanics in the eastern half of the 
Challis $1^{\circ} \times 2^{\circ}$ quadrangle, Idaho, in Bonnichsen, Bill, and Breckenridge, R.M., eds., Cenozoic geology of Idaho: Idaho Bureau of Mines and Geology Bulletin 26, p. 3-22.

McIntyre, D.H., and Hobbs, S.W., 1987, Geologic map of the Challis quadrangle, Custer County, Idaho: U.S. Geological Survey Geologic Quadrangle Map GQ-1599, scale 1:62,500.

McIntyre, D.H., Hobbs, S.W., Marvin, R.F., and Mehnart, H.H., 1976, Late Cretaceous and Eocene ages for hydrothermal alteration and mineralization, Bayhorse district and vicinity, Custer County, Idaho: Isochron/West, no. 16, p. 11-12.

Nilsen, T.H., 1977, Paleogeography of Mississippian turbidites in south-central Idaho, in Stewart, J.H., Stevens, C.H., and Fritsche, A.E., eds., Paleozoic paleogeography of the Western United States: Society of Economic Paleontologists and Mineralogists, Pacific Section, Pacific Coast Paleogeography Symposium 1, 1977, p. 275-299.

Oaks, R.Q., Jr., and James, W.C., 1980, The Kinnikinic Quartzite (Middle Ordovician) in the type area, central Idaho, and a new reference section near Arco, Idaho: Brigham Young University Geology Studies, v. 27, pt. 2, p. 1-9.

Paull, R.A., 1976, Evidence against Antler-age thrusts in south-central Idaho [abs.]: Geological Society of America Abstracts with Programs, v. 8, no. 5, p. 617-618.

Poole, F.G., and Sandberg, C.A., 1977, Mississippian paleogeography and tectonics of the Western United States, in Stewart, J.H., Stevens, C.H., and Fritsche, A.E., eds., Paleozoic paleogeography of the Western United States: Society of Economic Paleontologists and Mineralogists, Pacific Section, Pacific Coast Paleogeography Symposium 1, 1977, p. 67-85.

Ross, C.P., 1934a, Correlation and interpretation of Paleozoic stratigraphy in south-central Idaho: Geological Society of America Bulletin, v. 45, no. 5, p. 937-1000.

1934b, Geology and ore deposits of the Casto quadrangle, Idaho: U.S. Geological Survey Bulletin $854,135 \mathrm{p}$.

1937, Geology and ore deposits of the Bayhorse region, Custer County, Idaho: U.S. Geological Survey Bulletin 877, 161 p.

1947, Geology of the Borah Peak quadrangle, Idaho: Geological Society of America Bulletin, v. 58 , no. 12 , p. $1085-1160$. 1962a, Stratified rocks in south-central Idaho: Idaho Bureau of Mines and Geology Pamphlet 125, $126 \mathrm{p}$.

1962b, Paleozoic seas of central Idaho: Geological Society of America Bulletin, v. 73, p. 769-794.

1962c, Upper Paleozoic rocks in central Idaho: American Association of Petroleum Geologists Bulletin, v. 46, p. 384-387.

Ruppel, E.T., 1968, Geologic map of the Leadore quadrangle, Lemhi County, Idaho: U.S. Geological Survey Geologic Quadrangle Map GQ-733, scale 1:62,500.

1978, Medicine Lodge thrust system, eastcentral Idaho and southwest Montana: U.S. Geological Survey Professional Paper 1031, 23 p.

1980, Geologic map of the Patterson quadrangle, Lemhi County, Idaho: U.S. Geological Survey Geologic Quadrangle Map GQ-1529, scale $1: 62,500$.

1982, Cenozoic block uplifts in east-central Idaho and southwest Montana: U.S. Geological Survey Professional Paper 1224, $24 \mathrm{p}$.

Ruppel, E.T., and Lopez, D.A., 1981, Geologic map of the Gilmore quadrangle, Lemhi and Custer Counties, Idaho: U.S. Geological Survey Geologic Quadrangle Map GQ-1543, scale 1:62,500.

Ruppel, E.T., Ross, R.J., Jr., and Schleicher, David, 1975, Precambrian $\mathrm{Z}$ and Lower Ordovician rocks in east-central Idaho: U.S. Geological Survey Professional Paper 889-B, p. 25-34.

Sandberg, C.A., 1975, McGowan Creek Formation, new name for Lower Mississippian flysch sequence in east-central Idaho: U.S. Geological Survey Bulletin 1405-E, $11 \mathrm{p}$.

Scholten, Robert, and Ramspott, L.D., 1968, Tectonic mechanisms indicated by structural framework of central Beaverhead Range, Idaho-Montana: Geological Society of America Special Paper 104, $71 \mathrm{p}$.

Skipp, Betty, and Hait, M.H., Jr., 1977, Allochthons along the northeast margin of the Snake River Plain, Idaho: Wyoming Geological Association Guidebook, 29th Annual Field Conference, p. 499515 , scale 1:500,000.

Skipp, Betty, and Hall, W.E., 1975, Structure and Paleozoic stratigraphy of a complex of thrust plates in the Fish Creek Reservoir area, south-central Idaho: U.S. Geological Survey Journal of Research, v. 3 , no. 6 , p. 671-689, scale 1:62,500. 
Skipp, Betty, Sando, W.J., and Hall, W.E., 1979 [1980], The Mississippian and Pennsylvanian (Carboniferous) systems in the United States-Idaho: U.S. Geological Survey Professional Paper 1110-AA, p. AA1-AA43.

Tschanz, C.M., Killsgaard, T.H., and Seeland, D.A., 1974, Geology, in Tschanz, C.M., Killsgaard, T.H., Seeland, D.A., Van Noy, R.M., Ridenour, James, Zilka, N.T., Federspiel, F.E., Evans, R.K., Tuchek, E.T., and McMahan, A.B., Mineral resources of the eastern part of the Sawtooth National
Recreation area, Custer and Blaine Counties, Idaho: U.S. Geological Survey Open-File Report, $647 \mathrm{p}$.

Umpleby, J.B., 1913, Some ore deposits in northwestern Custer County, Idaho: U.S. Geological Survey Bulletin 539, $104 \mathrm{p}$.

Umpleby, J.B., Westgate, L.G., and Ross, C.P., 1930, Geology and ore deposits of the Wood River region, Idaho, with a description of the Minnie Moore and near-by mines, by D.F. Hewett: U.S. Geological Survey Bulletin 814, 250 p. 